\title{
РОССИЙСКИЙ РЫНОК КОРПОРАТИВНЫХ ОБЛИГАЦИЙ: ТЕНДЕНЦИИ И ПЕРСПЕКТИВЫ РАЗВИТИЯ
}

\author{
И. А. Алексеева, Е. В. Макарова \\ Байкальский государственный университет, г. Иркутск, Российская Федерация
}

\author{
Информация о статье \\ Дата поступления \\ 11 мая 2017 г. \\ Дата принятия к печати \\ 30 мая 2017 г. \\ Дата онлайн-размещения \\ 15 сентября 2017 г.

\section{Ключевые слова} \\ Облигации; корпоративные \\ облигации; инвестирование \\ в облигации; рынок \\ корпоративных облигаций
}

\begin{abstract}
Аннотация
В настоящее время в условиях экономической нестабильности облигации рассматриваются в качестве одного из наиболее надежных и перспективных инструментов инвестирования. В статье проводится анализ динамики показателей первичного и вторичного рынков корпоративных облигаций Российской Федерации за 2010-2016 гг., выявляются основные тенденции развития российского рынка корпоративного облигационного долга, дается оценка его современного состояния. Особое внимание уделяется причинам нестабильности российского облигационного рынка в 2014-2015 гг. Проводится анализ привлекательности российского рынка корпоративных облигаций для инвесторов в сопоставлении с рынком акций, для эмитента - на основе сравнения облигационного заимствования и банковского кредитования, обосновывается вывод о перспективах его развития.
\end{abstract}

\section{RUSSIAN CORPORATE BOND MARKET: TENDENCIES AND DEVELOPMENT PROSPECTS}

\author{
Irina A. Alekseeva, Elizaveta V. Makarova \\ Baikal State University, Irkutsk, Russian Federation
}

\section{Article info}

Received

May 11, 2017

Accepted

May 30, 2017

Available online

September 15, 2017

\section{Keywords}

Bonds; corporate bonds; investing in bonds; corporate bond market

\begin{abstract}
Now in the unsteady economic environment bonds are seen as one of the safest and most promising investment instruments. The authors analyze the dynamics of indicators of the primary and secondary corporate bond markets in the Russian Federation in 2010-2016. They draw out the main development trends in the Russian corporate bond debt market and assess its current state. Particular attention in this regard is given to the causes of instability of the Russian bond market in 2014-2015. The authors analyze the attractiveness of the Russian corporate bond market for investors against the stock market, and for issuers - based on borrowing money through bonds versus getting bank loans and draw conclusions on its development prospects.
\end{abstract}

Облигации - это долговые ценные бумаги. В системе международного фондового рынка они являются одним из наиболее надежных способов вложения капитала и имеют определенные преимущества в сравнении с долевыми ценными бумагами. С одной стороны, облигация, как и акция, - это эмиссионная ценная бумага, а значит, она может выпускаться в свободное обращение и тем самым выступать объектом спекуляции с целью получения дохода в виде разницы цены покупки и продажи. С другой стороны, облигация служит долговым документом, по которому эмитент принимает на себя исполнение обязательств в установленные условиями выпуска сроки независимо от своего финансового состояния. В соответствии с этими обязательствами инвестору гарантируется получение от эмитента в предусмотренный срок номинальной стоимости облигации или иного имущественного эквивалента, а также получение процента 
и (или) дисконта от номинальной стоимости облигации либо иные имущественные права.

Таким образом, по облигациям поток платежей известен заранее: четко фиксированы время выплат и их размер. Это значительно снижает уровень неопределенности денежных потоков по данному инструменту и в конечном итоге уменьшает риск инвесторов.

На зарубежных фондовых рынках отмеченные фракторы являются основными, они обеспечивают стабильность инвестициям, сделанным в облигации.

Интерес к выпуску облигаций проявляют и эмитенты. В развитых странах последние десятилетия наблюдается тенденция роста значимости облигационных заимствований как источника фринансирования инвестиций. В России корпоративные облигации могут выпускать акционерные общества (в соответствии со ст. 33 Федерального закона «Об акционерных обществах» от 26 декабря 1995 г. № 208-Ф3), общества с ограниченной ответственностью (согласно ст. 31 Федерального закона «Об обществах с ограниченной ответственностью» от 8 февраля 1998 г. № 14-Ф3). Следует отметить, что корпоративные облигации не дают инвестору право на участие в управлении делами эмитента, т. е. в сравнении с привлечением финансирования посредством рынка акций эмиссия корпоративных облигаций не приводит к перераспределению собственности эмитента и считается менее рискованным инструментом для предприятий развивающихся стран [1, с. 51].

Обозначенные преимущества облигаций являются определяющими для инвесторов и эмитентов в условиях стабильного развития экономики. Однако со второй половины 2014 г. российская экономика характеризуется неустойчивыми темпами развития. В этих условиях представляет интерес вопрос о сохранении заинтересованности инвесторов и эмитентов к данному финансовому инструменту.

По расчетам, основанным на данных информационного агентства «Сбондс», объем внутреннего рынка корпоративных облигаций по номинальной стоимости год от года растет непрерывным темпом. Так, за 2010-2016 гг. он вырос более чем в 3 раза: с 2,97 до 9,44 трлн р., относительно валового внутреннего продукта — с 6,4 до 11,0 \% (табл. 1, рис. 1).

Объем первичных размещений корпоративных облигаций по номиналу за рассматриваемый период также ежегодно показывает положительную динамику (рис. 2).

Объем рынка и новые размещения облигаций российских корпоративных эмитентов в 2010-2016 гг.*

\begin{tabular}{|c|c|c|c|c|c|c|c|}
\hline Показатель & 2010 & 2011 & 2012 & 2013 & 2014 & 2015 & 2016 \\
\hline Объем в обращении, трлн р. & 2,97 & 3,44 & 4,17 & 5,19 & 6,62 & 8,07 & 9,44 \\
\hline в том числе рыночные выпуски & 2,80 & 3,14 & 3,77 & 4,67 & 4,17 & 4,59 & 4,73 \\
\hline Доля рыночных выпусков в обращении, \% & 94 & 91 & 91 & 90 & 63 & 57 & 50 \\
\hline Темп роста объема в обращении, \% & - & 116 & 121 & 125 & 128 & 122 & 117 \\
\hline Темп роста объема рыночных выпусков, \% & - & 113 & 120 & 124 & 89 & 110 & 103 \\
\hline $\begin{array}{l}\text { Доля объема в обращении к валовому внутреннему } \\
\text { продукту, \% }\end{array}$ & 6,4 & 5,8 & 6,2 & 7,3 & 8,5 & 10,0 & 11,0 \\
\hline Объем размещения в течение года, трлн р. & 0,86 & 0,94 & 1,22 & 1,69 & 1,78 & 2,24 & 2,36 \\
\hline В том числе рыночные выпуски & 0,85 & 0,79 & 1,11 & 1,48 & 0,36 & 1,20 & 1,03 \\
\hline Доля рыночных выпусков в объеме размещения, \% & 98 & 84 & 91 & 87 & 20 & 53 & 43 \\
\hline Темп роста объема размещения, \% & - & 109 & 129 & 139 & 105 & 126 & 106 \\
\hline Темп роста объема размещения рыночных выпусков, \% & - & 93 & 140 & 134 & 24 & 333 & 86 \\
\hline Доля ста крупнейших эмитентов, \% & 35 & 36 & 36 & 41 & 60 & 45 & 50 \\
\hline
\end{tabular}

* Составлена по данным Института экономической политики им. Е. Т. Гайдара [2, с. 109], информационного агентства “Сбондс» и Росстата. URL: http://cbonds.ru/indexes; URL: http://www.gks.ru/wps/wcm/connect/rosstat_ main/rosstat/ru/statistics/accounts. 


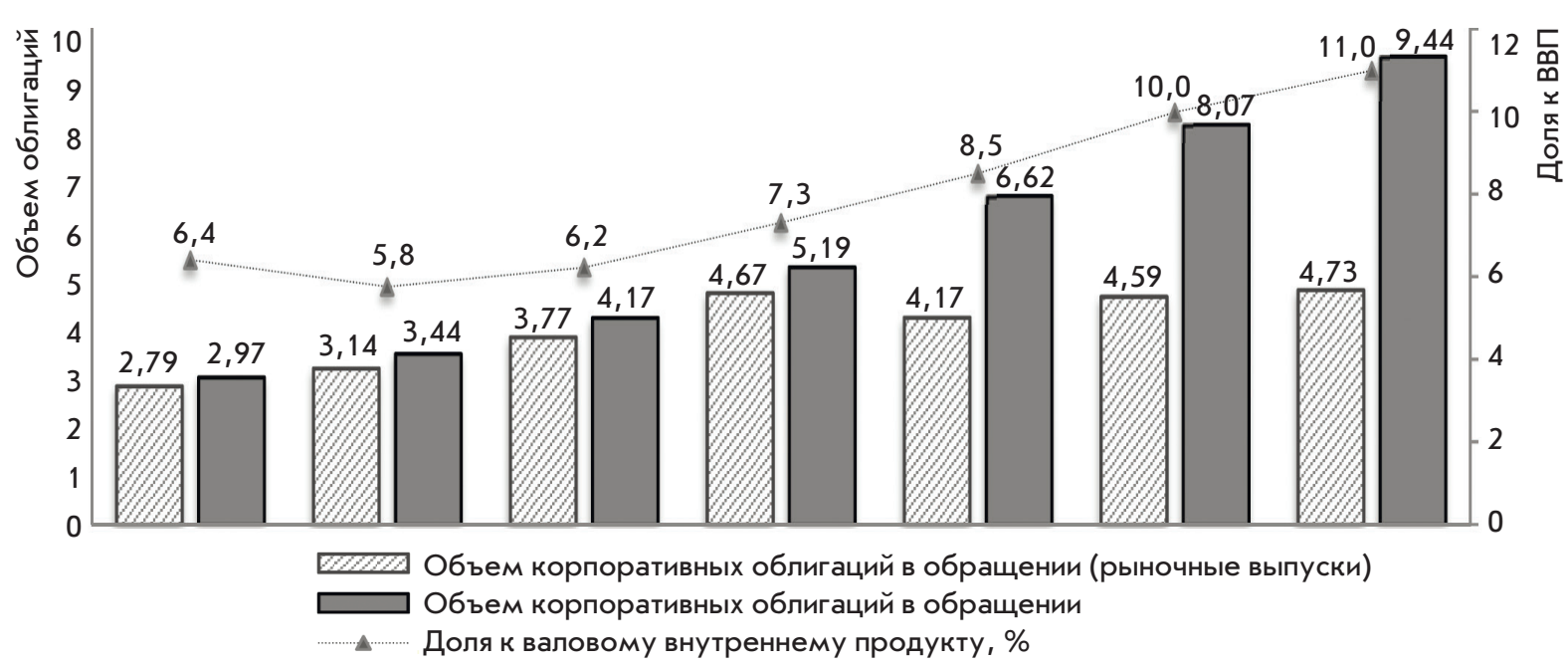

Рис. 1. Динамика стоимостного объема корпоративных облигаций, обращающихся на внутреннем рынке в 2010-2016 гг. (по состоянию на конец года), трлн р.

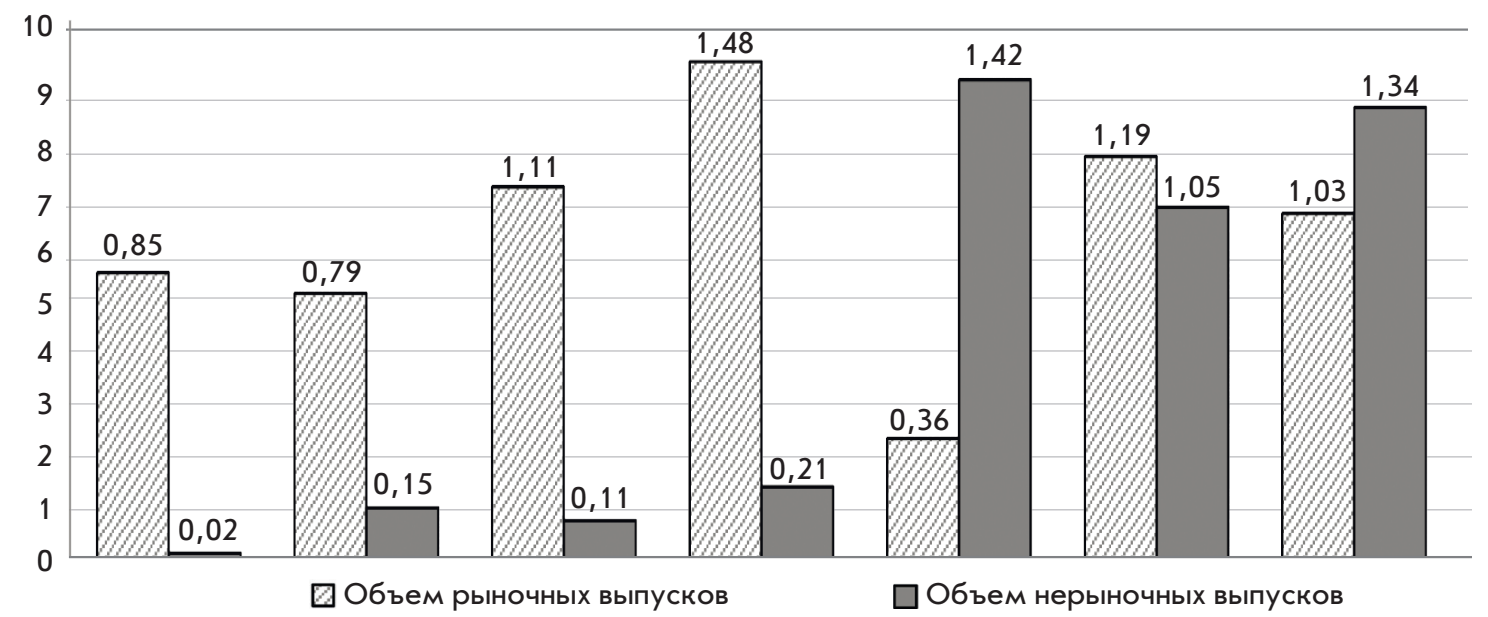

Рис. 2. Стоимостной объем размещения корпоративных облигаций в течение года за 2010-2016 гг., трлн р.

В 2016 г. объем размещения облигаций составил 2,37 трлн р. (без учета однодневных биржевых облигаций публичного акционерного общества «Банк ВТБ» на сумму 2,0 трлн р., являющихся по своей сути инструментом денежного рынка, а не рынка капитала), т. е. на 174,0\% больше, чем в 2010 г., и на 5,6\% больше, чем в 2015 г.

Однако, несмотря на очевидный ежегодный рост объема внутреннего российского облигационного рынка, следует отметить сокращение в 2014 г. объема корпоративных облигаций во вторичном обороте. Если в 2010-2013 гг. доля рыночных размещений составляла 84-98 \%, то в 2014 г. она была равна $20 \%$, в 2015-2016 гг. превысила уровень 2014 г. и составила 53 и 43 \% соответственно, однако это существенно ниже значений 2010-2013 гг. При этом снижение данного показателя в 2014-2016 гг. произошло как за счет резкого роста объемов нерыночных размещений, так и падения совокупного объема рыночных выпусков облигаций.

Основная причина таких изменений девальвация рубля в декабре 2014 г. и рост ключевой ставки Банка России до 17 \% годовых. В силу отсутствия возможности получения крупнейшими российскими заемщиками (с государственным участием в капитале) «дешевых денег» на зарубежных рынках произошел процесс замещения валютного долга рублевым. По итогам 2014 г. общий объем размещений рублевых корпоративных облигаций (рыночных и нерыночных выпусков) составил 1,78 трлн р. по сравнению с 1,69 трлн р. в 2013 г., т. е. он вырос всего на 2,5 \%. Однако если не учитывать нерыночное размещение выпуска облигаций нефтегазовой компании «Роснефть» на сумму 0,63 трлн р. в декабре 2014 г., то объем 
выпусков корпоративных облигаций в этот год составил бы лишь 1,16 трлн р., т. е. был бы на 32 \% ниже, чем в 2013 г. Столь крупное нерыночное размещение повлияло также и на показатель концентрации 10 эмитентов с самыми крупными объемами выпусков корпоративных облигаций в общем объеме размещений: по итогам 2014 г. он составил 60 \%, хотя годом ранее этот показатель был равен $41 \%$.

В 2015 г. рынок корпоративных облигаций российских эмитентов продолжил свое развитие. Постепенное снижение ключевой ставки Банка России, ограничение банковского кредитования и внешнего финансирования позволили увеличить объем рыночных выпусков корпоративных облигаций более чем в 3 раза в сравнении с 2014 г. (см. рис. 2). Высокий спрос на бумаги был обеспечен российскими банками, для которых вложения в облигации являлись альтернативой увеличения кредитного портфеля, а также негосударственными пенсионными фондами, получившими примерно 0,55 трлн р. в результате завершения пенсионной реформы.

Снижение ключевой ставки в 2016 г. до 10 \% способствовало уменьшению стоимости заимствований на российском облигационном рынке и, соответственно, увеличению эмиссионной активности корпоративных эмитентов. Положительное влияние на динамику рынка в 2016 г. оказывала также динамика инфляции, которая по итогам года составила 5,4\%. Указанные фракторы благоприятствовали росту объемов первичных размещений, и в 2016 г. стоимостной объем рыночных выпусков корпоративных облигаций вырос на $17 \%$ и составил 4,73 трлн р., что на 1 \% выше показателя 2013 г. Однако концентрация выпусков корпоративных облигаций по-прежнему остается высокой: по итогам 2016 г. на десятку крупнейших эмитентов приходилось 50 \% всей суммы эмиссии. Причем подавляющее большинство крупнейших эмитентов - компании с государственным участием. Без учета декабрьского размещения облигаций нефтегазовой компании «Роснефть» на 0,60 трлн р. доля таких эмитентов составила порядка $32 \%$. Соответственно, данный рынок все еще остается механизмом перераспределения финансовых ресурсов в пользу крупных государственных структур [2, с. 108], т. е. государственные компании заимствуют деньги у государственных структур.

Развитие рынка корпоративных облигаций в России сопровождается удлинением сроков заимствований (рис. 3).

Если в 2010-2012 гг. 45-47 \% выпусков корпоративных облигаций имели срок обращения до трех лет, то уже в 2013 г. произошло снижение доли коротких выпусков до $28 \%$ в пользу увеличения выпусков облигаций с длительными сроками погашения: по итогам года доля выпусков облигаций со сроком 10-15 лет составила $6 \%$, а со сроком свыше 15 лет достигла 17 \% (в 2010 г. эти доли составляли 1 и 3 \% соответственно). В 2014 г. данная тенденция сохранилась. В связи с обострившейся геополитической ситуацией и отсутствием возможности получения долгосрочного фринансирования на зарубежных
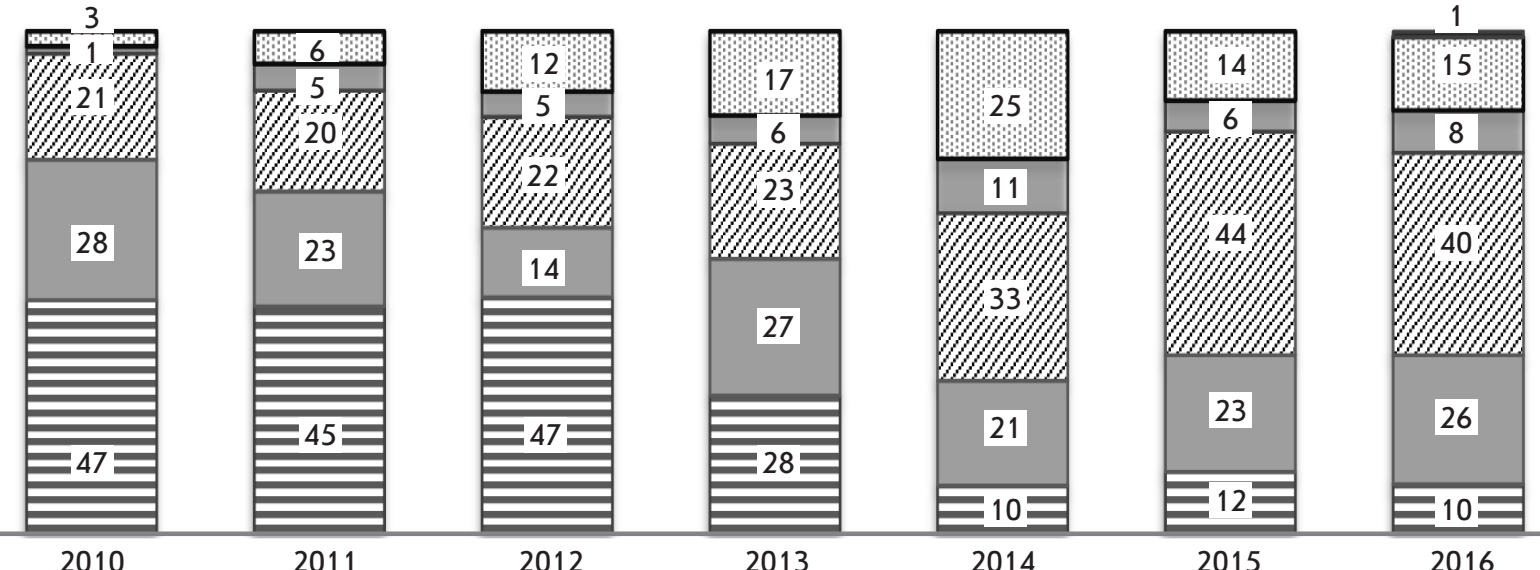

2012

$\square$ 10-15 лет

曰До 3 лет

$\square 3-5$ лет

ㄴ-10 лет

图 Свыше 15 лет

Без срока

Рис. 3. Структура новых выпусков корпоративных облигаций за 2010-2016 гг. по срокам до погашения, \%

Составлено по данным информационного агентства "Сбондс». URL: http://cbonds.ru/emissions 
рынках доля коротких выпусков сократилась до $10 \%$, тогда как доли выпусков облигаций со сроками 10-15 лет и свыше 15 лет достигли рекордных за рассматриваемый период значений - 11 и 25 \% соответственно. По итогам 2015 г. на фроне замедления инфляции, падения ставок на денежном рынке и ожиданий снижения в среднесрочной и долгосрочной перспективе ключевой ставки Банком России несколько снизилась доля долгосрочных выпусков со сроком 10-15 лет (до 6 \%) и свыше 15 лет (до $14 \%$ ) в пользу сроков 5-10 лет, 3-5 лет и до 3 лет, составивших 44, 23 и $12 \%$ соответственно.

Среди корпоративных облигаций, выпущенных в 2016 г., также преобладают инструменты со сроком обращения 5-10 лет (из анализа исключены данные по однодневным биржевым облигациям, выпущенным публичным акционерным обществом «Банк ВТБ»). Однако некоторые эмитенты, размещая относительно долгосрочные (и нередко нерыночные) выпуски в 2016 г., предусматривали по ним колл-опционы на более короткий период. В 2016 г. на российском рынке впервые появились бессрочные облигации, «Россельхозбанк» стал первым эмитентом, выпустившим бессрочные субординированные облигации по российскому праву, до этого такие облигации размещались только на международном рынке капитала.

Закономерным образом за 2010-2016 гг. менялась и отраслевая структура российского рынка корпоративных облигаций (рис. 4).
Так, если в 2010-2011 гг. более половины объема выпусков корпоративных облигаций относилось к секторам экономики, не связанным с рынком капиталов и нефтегазовой отраслью, то в 2012-2014 гг. наблюдалась тенденция ежегодного роста банковской сфреры и финансовых институтов и снижения доли иных отраслей экономики.

Начиная с 2015 г., в связи с ограничением доступа российских эмитентов к ресурсам внешнего фринансирования, происходит изменение отраслевой структуры выпусков: доля банковского сектора ежегодно снижается в пользу роста нефтегазовой отрасли и иных отраслей экономики.

По итогам 2016 г. впервые в истории доля выпусков корпоративных облигаций в нефтегазовом секторе (27\%) существенно превысила долю банковского сектора (20\%). Около 19 \% от совокупного объема выпусков пришлось на финансовые институты (ипотечных агентов, лизинговые, страховые и другие финансовые компании). По мнению специалистов, высокая доля эмитентов в фринансовом секторе характерна для развивающихся рынков капитала [3].

Офрициальные систематизированные данные о структуре базы инвесторов российского рынка облигаций отсутствуют. По аналитическим данным Московской биржи и по итогам торгов на Московской межбанковской валютной бирже в январе - апреле 2016 г. можно сказать, что коммерческие банки -

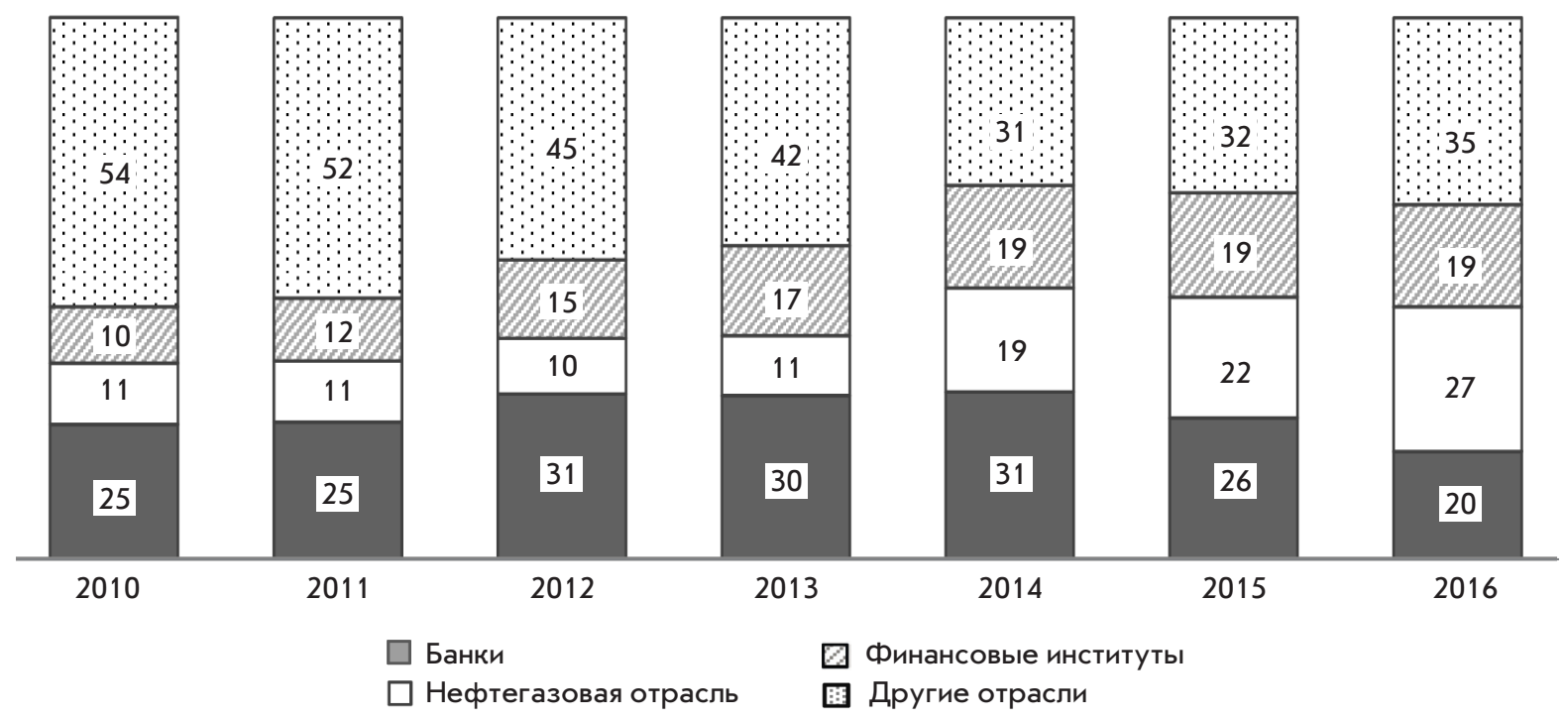

Рис. 4. Отраслевая структура выпусков корпоративных облигаций в 2010-2016 гг., \%

Составлено по данным информационного агентства “Сбондс». URL: http://cbonds.ru/emissions; саморегулируемой организации "Национальная ассоциация участников фондового рынка». URL: http://www.naufor.ru/download/pdf/factbook/ru/RFR2015.pdf 
наиболее активная категория инвесторов на вторичном рынке корпоративных облигаций. Их доля в общем обороте составляет 55 \%'. Тот фракт, что банки являются крупными держателями облигаций и эмитентами потенциально ослабляет фринансовую устойчивость облигационного рынка (особенно в случае углубления кризиса в банковском секторе) [4, с. 173].

В России остро стоит проблема перевода больших объемов сбережений (особенно фризических лиц) из пассивной формы в активную, т. е. их вовлечения в воспроизводственный процесс в качестве инвестиций [5, с. 7]. По мнению экспертов саморегулируемой организации «Национальная ассоциация участников фондового рынка» (СРО «НАУФОР»), для успешного функционирования российского рынка ценных бумаг доля частных инвесторов в общем обороте должна составлять 10-20\%². На сегодняшний день, несмотря на существенный инвестиционный потенциал российских частных инвесторов, она равна 4 \%. По официальной статистике Банка России, по состоянию на 1 января 2017 г. общий объем вкладов населения в рублях в банковской системе страны превысил 24 трлн р. По оценкам экспертов, общий объем сбережений домохозяйств составляет порядка 35 трлн р. (это без учета средств наиболее обеспеченной части населения, выведенных в оффршоры и иностранные активы) $)^{3}$. Часть этих ресурсов потенциально возможно вовлечь в оборот рынка корпоративных облигаций российских эмитентов.

Наблюдающаяся крайне низкая вовлеченность розничных инвесторов в рынок корпоративных облигаций объясняется невысоким уровнем финансовой грамотности населения (92\% российских граждан не знает сути и правил инвестиционной деятельности и имеет слабый уровень интереса к фрондовому рынку [6, с. 72]), а также стандартным уровнем налогообложения доходов от инвестирования в них.

${ }^{1}$ ММВБ. Российский рынок облигаций. Май 2016 // Ассоциация региональных банков России. URL: http: // www.asros.ru/public/files/12/11404-gusakov_moex_ obligachii_26052016.pdf.

2 Российский фондовый рынок и создание международного финансового центра. Идеальная модель фондового рынка России на долгосрочную перспективу (до 2020 г.). URL: http://naufor.ru/tree. asp? $\mathrm{n}=5563 \& \mathrm{hk}=20070122$.

${ }^{3}$ Материалы научного семинара «Анализ развития российского финансового рынка: дисбалансы финансовой системы» / / НИУ Высшая школа экономики. URL: http://www.liberal.ru/articles/6985.
Решению проблемы крайне низкой активности частного инвестора должен способствовать законопроект об отмене налога на доходы физических лиц, получаемых с корпоративных облигаций ${ }^{4}$, одобренный 1 декабря 2016 г. Правительством РФ. В июне 2016 г. Государственная Дума во втором и третьем чтении приняла закон о снижении ставки налога на прибыль юридических лиц по купонному доходу корпоративных облигаций российских эмитентов с 20 до $15 \%$. С целью снижения налоговой нагрузки на фризических лиц, осуществляющих деятельность на рынке ценных бумаг, и привлечения ликвидности на российский фондовый рынок с 1 января 2015 г. введен в практику профессиональных участников рынка ценных бумаг (брокеров и управляющих) индивидуальный инвестиционный счет (ИИС), позволяющий возвращать в качестве льготы от государства $13 \%$ от внесенной на него суммы, а также получать доход по акциям и облигациям. Однако сумма, с которой предоставляется вычет, ограничена ежегодным взносом в размере 400 тыс. Р. Министерство финансов и СРО «НАУФОР» предлагают увеличить максимальную стартовую сумму, вносимую на ИИС, до 1 млн р. ${ }^{5}$ Мировая практика показывает, что применение налоговых льгот в области инвестирования в ценные бумаги целесообразно с точки зрения их положительного влияния на формирование нового капитала в экономике [7, с. 100].

Рассмотрим теперь основные тенденции развития и текущее состояние вторичного рынка корпоративных облигаций российских эмитентов. Для анализа используются данные по объему торгов негосударственными облигациями на фондовом и денежном рынках Московской биржи (без учета размещений новых выпусков). В связи с особенностями раскрытия информации объем сделок с корпоративными, суборедеральными и муниципальными облигациями показывается суммарно (табл. 2). По информации СРО «НАУфОР», оборот корпоративных облигаций при этом составляет около $97 \% 6$.

${ }^{4}$ Релиз «Cbonds». 2 февраля 2016 г. / / Информационное агентство "Сбондс». URL: http://ru.cbonds. info/news/item/858437.

${ }^{5}$ Сообщения информационных агентств. 16 февраля 2017 г. / / Министерство финансов : офиц. сайт. URL: http: / / m.minfin.ru/common/upload/library/2017 /02/ main/16.02.2017.pdf.

6 URL: http://www.naufor.ru/download/pdf/ factbook/ru/RFR2015.pdf. 
Таблица 2

Структура и объем торгов с негосударственными облигациями на фондовом и денежном рынках Московской биржи в 2010-2016 гг.*

\begin{tabular}{|l|r|r|r|r|r|r|r|}
\hline \multicolumn{1}{|c|}{ Показатель } & 2010 & 2011 & 2012 & 2013 & 2014 & 2015 & 2016 \\
\hline Объем фондового рынка, трлн р. & 5,1 & 5,7 & 5,8 & 6,7 & 4,7 & 5,0 & 4,6 \\
\hline Темп роста фондового рынка, \% & - & 112 & 102 & 116 & 70 & 106 & 92 \\
\hline Доля фондового рынка в общем объеме сделок, \% & 15 & 12 & 9 & 6 & 5 & 5 & 3 \\
\hline Объем денежного рынка, трлн р. & 28,5 & 40,0 & 61,8 & 97,4 & 83,3 & 92,8 & 179,9 \\
\hline Темп роста денежного рынка, \% & - & 140 & 155 & 158 & 86 & 111 & 194 \\
\hline Доля денежного рынка в общем объеме сделок, \% & 85 & 88 & 91 & 94 & 95 & 95 & 97 \\
\hline Общий объем сделок, трлн р. & 33,7 & 45,7 & 67,5 & 104,1 & 88,0 & 97,8 & 184,5 \\
\hline
\end{tabular}

* Составлена по данным Московской биржи. URL: https://moex.com/s868.

В 2010-2013 гг. рост сделок с негосударственными облигациями наблюдался как на фондовом, так и на денежном рынке. На фондовом рынке рост составил 30 \% (с 5,1 трлн р. в 2010 г. до 6,7 в 2013 г.), а объем операций на денежном рынке вырос более чем в 3,4 раза (с 28,5 трлн р. до 97,4 соответственно), составив по итогам 2013 г. $94 \%$ от всех операций с негосударственными облигациями. Столь бурный рост сделок на денежном рынке был обусловлен увеличением количества сделок типа РЕПО (Repurchase Agreement, REPO), и хотя вследствие кризисных явлений 2014 г. произошло снижение объема сделок на денежном рынке на $14 \%$ (с 97,4 трлн р. в 2013 г. до 83,3 в 2014 г.), введение способа фринансирования банковской системы посредством сделок РЕПО с центральным контрагентом [8] позволило поддержать объемы совершаемых сделок в 2015 г. (рост относительно 2014 г. составил $11 \%)$, что и привело к беспрецедентному увеличению количества сделок с негосударственными облигациями на денежном рынке в 2016 г. - 88 \% за год. В конце декабря 2016 г. доля сделок денежного рынка в стоимости биржевых сделок с негосударственными облигациями достигла абсолютного рекорда $-97 \%$.

В отличие от денежного рынка, на фондовом рынке в 2014 г. произошло значительное снижение биржевого оборота: рыночные сделки с облигациями упали до минимума и в денежном выражении составили 4,7 трлн р., что на 30 \% меньше, чем годом ранее. Это очень значительное падение оборотов, даже в кризисные 20082009 гг. спад был на уровне $4-5 \%^{7}$. Если в целом за 2010-2016 гг. на денежном рынке Московской биржи объем сделок вырос более чем в 6 раз (с 28,5 до 179,9 трлн р.), то объемы рыночных сделок с негосу-

7 URL: http: //www.naufor.ru/download/pdf/ factbook/ru/RFR2015.pdf. дарственными облигациями на фрондовом рынке группы снизились, что обусловлено ограниченностью базы внутренних и иностранных инвесторов. Очевидно, что рынок корпоративных облигаций все больше превращается в инструмент денежного рынка, так как по итогам 2016 г. только 3 \% сделок с негосударственными облигациями проходили на фондовом рынке, что существенно повышает риски ликвидности и объективности ценообразования на вторичном рынке корпоративных облигаций. Именно проблема низкой ликвидности является главной на фондовом рынке России [9, с. 94]. Низкая ликвидность характерна для рынков корпоративных облигаций всех развивающихся стран [10, с. 31].

В результате анализа первичного и вторичного рынков корпоративных облигаций российских эмитентов можно заключить, что их состояние не может характеризоваться однозначно позитивно. Российский рынок корпоративных облигаций имеет признаки развивающегося рынка:

- доминирование эмитентов - крупных компаний топливно-нефтегазового и финансового секторов;

- ничтожно низкая доля частных инвесторов на вторичном рынке;

- низкая ликвидность рынка.

В таких условиях интересным представляется вопрос о том, насколько заинтересованы инвесторы и эмитенты в выходе на рынок корпоративных облигаций.

Анализ показал, что в течение 2014 г. существенно выросла стоимость денег на российском рынке. Если в начале года средневзвешенная доходность к погашению корпоративных облигаций, включенных в индекс IFX-Cbonds, составляла 8,2 \%, то с марта, в связи с обострившейся геополитической ситуацией, доходность к погашению рублевых облигаций начала расти. Средневзвешенную доходность к погашению инструментов, вхо- 
дящих в индекс IFX-Cbonds, демонстрирует индекс IFX-CbondsYTM. В октябре 2014 г. на фоне падения цен на нефть, ослабления рубля к доллару США и евро доходность корпоративных облигаций в составе индекca IFX-Cbonds превысила $10 \%$, а в начале фревраля 2015 г. достигла 15,9 \% (после увеличения в декабре 2014 г. ключевой ставки Банка России до 17 \%) (рис. 5). Вследствие увеличения процентных ставок произошло снижение интереса корпоративных эмитентов, выразившееся в резком сокращении объемов рыночных эмиссий.

Одновременно с ростом процентных ставок в экономике России в 2014 г. произошло снижение цен на обращающиеся на вторичном рынке корпоративные облигации. В результате произошло падение индекса IFX-Cbonds (табл. 3). По итогам 2014 г., после пяти лет достаточно выгод-

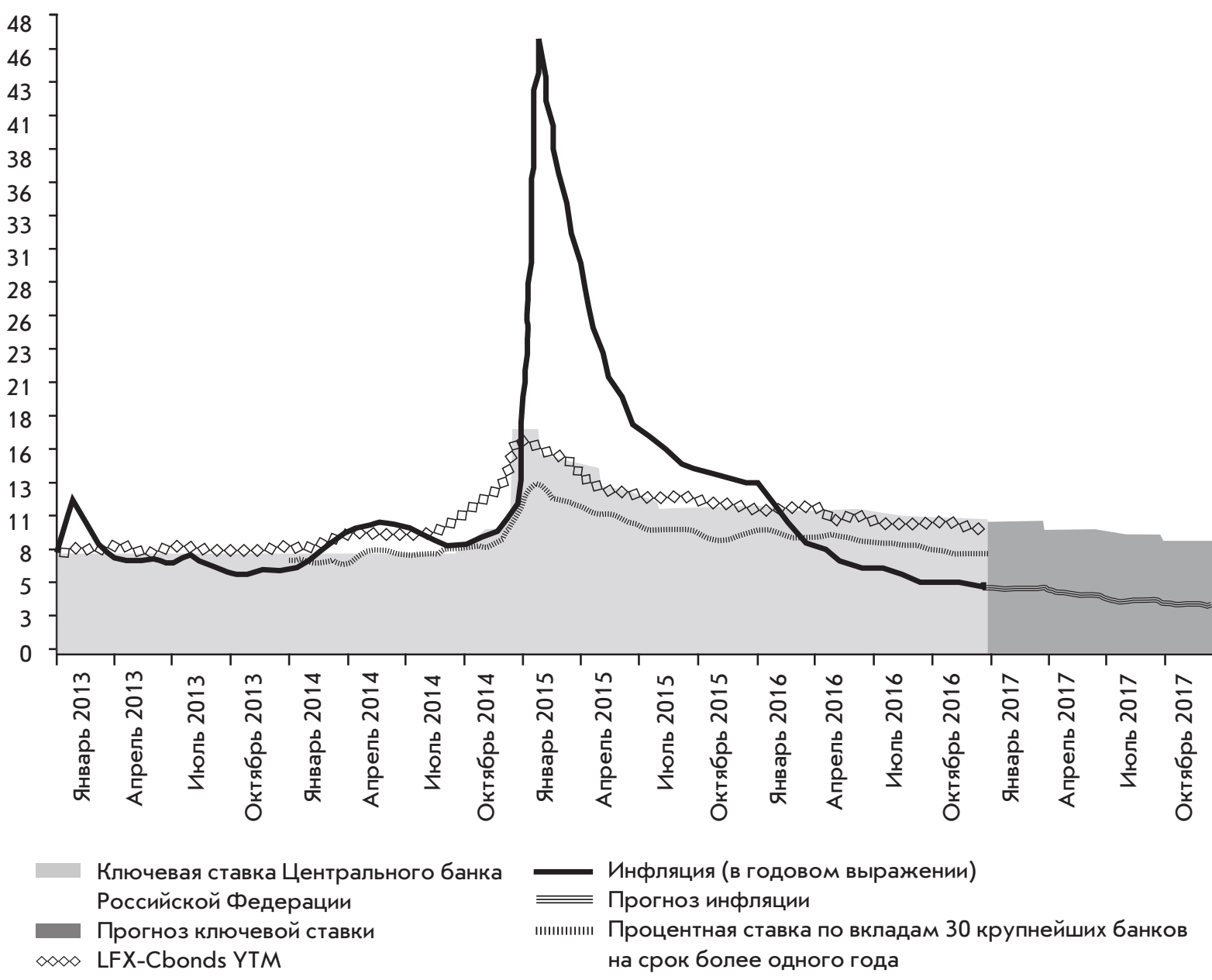

Рис. 5. Динамика индекса IFX-CbondsYTM и процентных ставок в экономике России в 2010-2016 гг., \%

Составлено по данным Центрального банка Российской Федерации. URL: http://www.cbr.ru/ statistics/?Prtld=sors; информационного агентства «Сбондс». URL: http://cbonds.ru/indexes; Росстата. URL: http://www.gks.ru/wps/wcm/connect/rosstat_main/rosstat/ru/statistics/accounts

Таблица 3

Сравнение годового прироста индекса корпоративных облигаций IFX-Cbonds, индекса Московской межбанковской валютной биржи и годового уровня инфляции за 2013-2016 гг.

\begin{tabular}{|c|c|c|c|c|}
\hline \multirow{2}{*}{ Показатель } & \multicolumn{4}{|c|}{ Годовая доходность, \% } \\
\hline & 2013 & 2014 & 2015 & 2016 \\
\hline Индекс корпоративных облигаций IFX-Cbonds & 8,86 & $-1,43$ & 18,30 & 12,70 \\
\hline Индекс Московской межбанковской валютной биржи & 1,99 & $-7,15$ & 26,12 & 25,69 \\
\hline Уровень инфоляции & 6,45 & 11,36 & 12,91 & 5,40 \\
\hline
\end{tabular}


ных вложений в корпоративные облигации, показатель возврата на инвестиции оказался отрицательным, т. е. инвестиции как в корпоративные облигации, так и в акции российских компаний оказались убыточными. На рынке корпоративных облигаций инвесторы могли потерять 1,43 \% вложений, на рынке акций - 7,15 \%. Таким образом, рынок корпоративных облигаций оказался более устойчивым, чем рынок акций: потери инвесторов, вложивших в корпоративные облигации, оказались значительно ниже потерь инвесторов, купивших акции.

В середине 2015 г. ставки доходности облигационного рынка стали снижаться, но в целом по итогам года, в отличие от 2014 г., доходность корпоративных облигаций и динамика индекса Московской межбанковской валютной биржи оказалась положительными и превысили темп инфрлции. Более того, в течение года уровни доходности корпоративных облигаций значительно превышали уровни, сложившиеся на рынке в докризисном периоде (2012 - первая половина 2014 г.).

В 2016 г. развитие российского рынка корпоративных облигаций сопровождалось постепенной стабилизацией экономики страны (укреплением курса рубля, снижением уровня инфляции и процентных ставок и другими факторами). Положительные результаты были достигнуты как с помощью инструментов фондового, так и долгового рынков, которые в 2-5 раз превысили уровень инфляции за тот же период (см. табл. 3). Как можно убедиться, с начала 2016 г. доходность к погашению корпоративных облигаций была выше ставок по вкладам в адекватных по кредитному качеству банках и превысила годовой уровень инфляции (см. рис. 4).
По прогнозам Минэкономразвития и Банка России, инфляция на конец 2017 г. составит 3,8-4,0 \%. Замедление инфляции приведет к дальнейшему снижению уровня ключевой ставки Центрального банка. Согласно консенсус-прогнозу аналитиков, опрошенных инфрормационным агентством «Bloomberg» [11], Банк России к концу 2017 г. снизит ключевую ставку до 8,5%, что обеспечит аналогичную динамику процентных ставок во всех сегментах рынка рублевых облигаций. Это должно стать основой сохранения высокого спроса на корпоративные облигации российских эмитентов со стороны инвесторов.

Для анализа заинтересованности эмитента в выходе на рынок корпоративных облигаций, сравним стоимость банковских кредитов (выраженную в процентной ставке по кредиту) и стоимость заимствования на облигационном рынке (выраженную в доходности облигаций к погашению). Рассмотрим среднегодовые ставки банков по кредитам юридическим лицам с разделением по сроку привлечения заемных средств, а также средние за год доходности к погашению корпоративных облигаций, входящих в индексы Cbonds-CBIRU 1-3Y (наиболее ликвидные инструменты рынка со сроком погашения 1-3 года) и Cbonds-CBIRU 3-5Y (наиболее ликвидные инструменты рынка со сроком погашения 3-5 лет) (табл. 4).

С учетом приведенных данных (см. табл. 4) можно говорить о большей привлекательности заимствований с точки зрения стоимости фондирования для компаний на облигационном рынке, нежели в кредитной организации. Только в 2015 г. кредиты на 3-5 лет обходились предприятиям дешевле, чем выпуск облигаций.

Сравнение средних процентных ставок по банковским кредитам и доходности корпоративных облигаций к погашению в 2013-2016 гг.*

\begin{tabular}{|l|l|r|r|r|r|}
\hline \multirow{2}{*}{ Срок погашения } & \multicolumn{1}{|c|}{ Показатель } & \multicolumn{1}{|c|}{2013} & \multicolumn{1}{c|}{2014} & \multicolumn{1}{c|}{2015} & \multicolumn{1}{c|}{2016} \\
\hline \multirow{3}{*}{$1-3$ года } & Кредит, \% & 11,71 & 11,89 & 15,62 & 13,03 \\
\cline { 2 - 6 } & Облигации, \% & 8,18 & 10,36 & 12,95 & 10,56 \\
\cline { 2 - 6 } & Отклонение, процентные пункты & 3,53 & 1,53 & 2,67 & 2,47 \\
\hline \multirow{3}{*}{$3-5$ лет } & Кредит, \% & 11,26 & 11,41 & 14,27 & 13,06 \\
\cline { 2 - 6 } & Облигации, \% & 8,42 & 10,92 & 14,42 & 10,54 \\
\cline { 2 - 6 } & Отклонение, процентные пункты & 2,84 & 0,49 & $-0,15$ & 2,52 \\
\hline
\end{tabular}

* Составлена по данным информационного агентства «Сбондс». URL: http://cbonds.ru/indexes; Центрального банка Российской Федерации. URL: http: / / www.cbr.ru/statistics/?Prtld=sors. 
Банковское кредитование менее интересно для компаний также и в силу того, что срок предоставления денег по кредитам короче по сравнению с облигационными займами (кредиты, выдаваемые на срок свыше трех лет, занимают третью часть от общего объем кредитования в России) [5, с. 10], тогда как на облигационном рынке в последние годы наблюдается тенденция удлинения сроков заимствования: срок погашения 40 \% выпусков облигаций в 2016 г. составил 5-10 лет. Привлекательность для потенциальных эмитентов финансирования посредством облигационного рынка подтверждается и растущей в последние годы долей объема корпоративных облигаций в обращении в соотношении с объемом рынка корпоративных кредитов [12].

Хотя статистические данные свидетельствуют, что обслуживание долга по корпоративным облигациям в среднем обходится предприятию дешевле, привлечение заемных ресурсов на финансовом рынке требует существенно большего количества времени, необходимого на подготовку и эмиссию облигационного займа [13, с. 19]. Однако уже в настоящее время для стимулирования эмиссионной активности российских предприятий и повышения доступ- ности облигационного займа Банк России осуществляет мероприятия, направленные на сокращение периода между принятием эмитентом решения о выпуске облигаций и размещением этого выпуска до 24 ч. Такие мероприятия призваны способствовать разгрузке балансов кредитных организаций $[14$, с. 52]. Сокращение времени на подготовку и эмиссию займа и тот фракт, что кредитные ставки банков превосходят среднюю доходность к погашению на рынке корпоративного долга, способствуют ожидаемому росту первичных размещений облигаций российскими эмитентами.

Проведенный анализ показывает, что развитие внутреннего рынка облигаций российских эмитентов становится одним из необходимых условий повышения устойчивости российской экономики к внешним факторам и формирования новой модели роста в условиях санкций $[15$, с. 295]. С учетом того что потенциально сохраняется высокая заинтересованность в участии на рынке корпоративных облигаций как эмитентов, так и инвесторов, можно предположить, что данный рынок в качестве инструмента инвестирования и привлечения инвестиций корпоративным сектором экономики в России будет только расти.

\section{СПИСОК ИСПОЛЬЗОВАННОЙ ЛИТЕРАТУРЫ}

1. Хмелев И. Б. Анализ динамики использования инструментов финансового рынка компаниями развивающихся стран / И. Б. Хмелев, М. А. Новикова / / Транспортное дело России. - 2014. — № 2. - С. 50-52.

2. Российская экономика в 2016 году: тенденции и перспективы / под ред. С. Г. Синельникова-Мурылева, А. Д. Радыгина. - М. : Изд-во Ин-та Гайдара, 2017. - 520 с.

3. Швецов С. А. Российский финансовый рынок: вызовы, проблемы и перспективы [Электронный ресурс] : докл. на 17-й Междунар. науч. конф. по проблемам развития экономики и общества / С. А. Швецов, Н. И. Берзон. - Режим доступа: https://www.hse.ru/science/reports.

4. Галенская К. В. Облигации или банковские кредиты: выбор компаний и реакция инвесторов на российском фондовом рынке / К. В. Галенская, Т. В. Теплова / / Управленческий учет и фринансы. — 2016. - Т. 3. С. 172-197.

5. Бадилина Л. П. Активизация инвестиционных процессов в Российской Федерации с использованием рынка ценных бумаг / Л. П. Бадилина, Н.А.Звягинцева / / Известия Иркутской государственной экономической академии. - 2016. - Т. 26, № 1. - C. 5-14. - DOI: 10.17150/1993-3541.2016.26(1).5-14.

6. Максимова А. А. Целевые ориентиры и положительные эффеекты повышения уровня фринансовой грамотности населения / А. А. Максимова, М. С. Сергейчик / / Вестник Томского государственного педагогического университета. - 2015. - № 5 (158). - С. 69-74.

7. Дюрягин А. В. Инвестиционные стимулы для индивидуальных инвесторов в России и мире / А. В. Дюрягин / / Российский внешнеэкономический вестник. - 2013. - № 3. - С. 97-103.

8. Сорокина Л. Н. Рынок операций РЕПО: пути возможного развития [Электронный ресурс] / Л. Н. Сорокина, В.Д.Сафошкин / / Гуманитарные научные исследования. - 2015. — № 11. — Режим доступа: http: // human.snauka.ru/2015/11/12915.

9. Анализ современного состояния рынка акций России / К. А. Малышенко, В. А. Малышенко, О. Ю. Гребенник, Е. В. Головлева / / Современные тенденции развития науки и технологий : по материалам 16-й Междунар. науч.-практ. конф., Белгород, 30 июля 2016 г. - Белгород : Агентство перспектив. науч. исслед., 2016. Вып. 11-10. - С. 92-96.

10. Запевалова Е. С. Выбор показателя ликвидности для российского рынка корпоративных облигаций / Е. С. Запевалова / / Управленческий учет и финансы. - 2016. - № 1. - С. 30-39.

11. Смертин П. Консенсус-прогноз: ЦБ РФ сохранит ставку на уровне $10 \%$, но снижение не за горами [Электронный ресурс] / П. Смертин. - Режим доступа: http: / /tass.ru/ekonomika/4119266. 
12. Шпилева М. В. Проблемы развития рынка корпоративных облигаций в России [Электронный ресурс] / М. В. Шпилева / / Бизнес и общество. — 2016. — № 4 (12). — Режим доступа: http: / / busines-society.ru / 2016 / num-4-12/6_shpileva.pdf.

13. Андреева А. К. Сравнение привлекательности корпоративных облигаций и банковских кредитов для заемщиков / А. К. Андреева / / Инновационная наука. - 2015. — № 6 (6). - С. 18-19.

14. Чайковская Е. Красный апельсин, или Успеть за 24 часа [Электронный ресурс] / Е. Чайковская / / Cbonds Review. - 2015. - № 4. - С. 52-55. - Режим доступа: http://review.cbonds.info/article/magazines/4273.

15. Соколова Т. В. Анализ факторов, влияющих на развитие рынка корпоративных и государственных рублевых облигаций / Т. В. Соколова / / Управление корпоративными финансами. — 2015. — № 5-6 (71-72). C. 294-307.

\section{REFERENCES}

1. Khmelev I. B., Novikova M. A. Analysis of Dynamics of Use Financial Market Instruments By Companies From Developing Countries. Transportnoe delo Rossii = Transport Business of Russia, 2014, no. 2, pp. 50-52. (In Russian).

2. Sinel'nikov-Murylev S. G., Radygin A. D. (eds). Rossiiskaya ekonomika v 2016 godu: tendentsii i perspektivy [Russian Economy in 2016: Tendencies and Prospects]. Moscow, Gaidar Institute Publ., 2017. 520 p.

3. Shvetsov S. A., Berzon N. I. Rossiiskii finansovyi rynok: vyzovy, problemy i perspektivy. Doklad na 17-i Mezhdunarodnoi nauchnoi konferentsii po problemam razvitiya ekonomiki $i$ obshchestva [Russian Financial Market: Challenges, Problems and Prospects. The report at $17^{\text {th }}$ International Scientific Conference on Economy and Society Development]. Available at: https://www.hse.ru/science/reports. (In Russian).

4. Galenskaya K. V., Teplova T. V. Bonds or Bank Credits: the Choice of Companies and Reaction of Investors at the Russian Stock Market. Upravlencheskii uchet i finansy= Management Accounting and Finance, 2016, vol. 3, pp. 172-197. (In Russian).

5. Badilina L. P., Zvyagintseva N. A. Enhancing investment processes in the Russian Federation through the securities market. Izvestiya Irkutskoi gosudarstvennoi ekonomicheskoi akademii = Izvestiya of Irkutsk State Economics Academy, 2016, vol. 26, no. 1, pp. 5-14. DOI: 10.17150/1993-3541.2016.26(1).5-14. (In Russian).

6. Maksimova A. A., Sergeichik M. S. Target reference points and positive effects of increase of financial literacy level of the population. Vestnik Tomskogo gosudarstvennogo pedagogicheskogo universiteta = Tomsk State Pedagogical University Bulletin, 2015, no. 5 (158), pp. 69-74. (In Russian).

7. Dyuryagin A. V. Investment incentives for individual investors in Russia and abroad. Rossiiskii vneshneekonomicheskii vestnik = Russian Foreign Economic Journal, 2013, no. 3, pp. 97-103. (In Russian).

8. Sorokina L. N., Safoshkin V. D. Repo market: ways of possible development. Gumanitarnye nauchnye issledovaniya = Humanities Scientific Researches, 2015, no. 11. Available at: http://human.snauka.ru/2015/11/12915. (In Russian).

9. Malyshenko K. A., Malyshenko V. A., Grebennik O. Yu., Golovleva E. V. Analysis of the current state of the market shares of Russia. In Tkacheva E.P. (ed.). Sovremennye tendentsii razvitiya nauki i tekhnologii. Materialy 16-i Mezhdunarodnoi nauchno-prakticheskoi konferentsii. Belgorod, 30 iyulya 2016 g. [Modern Trends in Development of Science and Technologies. Materials of the $13^{\text {th }}$ International Research Conference. Belgorod, July 30, 2016]. Belgorod, Agency for Promising Research Publ., 2016, iss. 11-10, pp. 92-96. (In Russian).

10. Zapevalova E. S. Choice of Liquidity Index for the Russian Corporate Bond Market. Upravlencheskii uchet i finansy = Management Accounting and Finance, 2016, no. 1, pp. 30-39. (In Russian).

11. Smertin P. Konsensus-prognoz: TsB RF sokhranit stavku na urovne $10 \%$, no snizhenie ne za gorami [Consensus Forecast: the Central Bank of Russia Will Maintain the $10 \%$ Rate, but the Decrease Is Round the Corner]. Available at: http: / /tass.ru/ekonomika/4119266. (In Russian).

12. Shpileva M. V. Problems of development of corporate bond market in Russia. Biznes $i$ obshchestvo = Business and Society, 2016, no. 4 (12). Available at: http://busines-society.ru/2016/num-4-12/6_shpileva. pdf. (In Russian).

13. Andreeva A. K. Comparison of Attractiveness of Corporate Bonds and Bank Loans for Borrowers. Innovatsionnaya nauka = Innovative Science, 2015, no. 6, pp. 18-19. (In Russian).

14. Chaikovskaya E. Red Orange or to Do In 24 Hours. Cbonds Review, 2015, no. 4, pp. 52-55. (In Russian).

15. Sokolova T. V. Analysis of the Factors Affecting the Development of the Corporate and Government Ruble Denominated Bond Market. Upravlenie korporativnymi finansami= Management of Corporate Finance, 2015, no. 5-6 (71-72), pp. 294-307. (In Russian).

\section{Информация об авторах}

Алексеева Ирина Анатольевна - кандидат экономических наук, доцент, кафедра банковского дела и ценных бумаг, Байкальский государственный университет, 664003, г. Иркутск, ул. Ленина, 11, e-mail: ialekseeva28_02@mail.ru.

Макарова Елизавета Витальевна - магистрант, кафедра банковского дела и ценных бумаг, Байкаль-

\section{Authors}

Irina A. Alekseeva - PhD in Economics, Associate Professor, Department of Banking and Securities, Baikal State University, 11 Lenin St., 664003, Irkutsk, Russian Federation, e-mail: ialekseeva28_02@mail.ru.

Elizaveta V. Makarova - Master Degree Student, Department of Banking and Securities, Baikal 
ский государственный университет, 664003, г. Иркутск, ул. Ленина, 11, e-mail: elizaveta.makarova@ gmail.com.

\section{Для цитирования}

Алексеева И. А. Российский рынок корпоративных облигаций: тенденции и перспективь развития / И. А. Алексеева, Е. В. Макарова // Известия Байкальского государственного университета. - 2017. - T. 27, № 3. - C. 389-400. - DOI: $10.17150 / 2500-2759.2017 .27(3) .389-400$.
State University, 11 Lenin St., 664003, Irkutsk, Russian Federation, e-mail: elizaveta.makarova@gmail.com.

\section{For Citation}

Alekseeva I. A., Makarova E. V. Russian Corporate Bond Market: Tendencies and Development Prospects. Izvestiya Baykal'skogo gosudarstvennogo universiteta $=$ Bulletin of Baikal State University, 2017, vol. 27, no. 3, pp. 389-400. DOI: 10.17150/2500-2759.2017.27 (3).389-400. (In Russian). 